\title{
EVALUATION OF DIFFERENT PLANT DERIVED OILS AS WOOD PRESERVATIVES AGAINST SUBTERRANEAN TERMITE Odontotermes obesus
}

\author{
Sohail Ahmed ${ }^{1}$, Rushda Fatima², Babar Hassan ${ }^{1, \star}$
}

\begin{abstract}
The study assessed the effect of jatropha, linseed, eucalyptus, neem and jojoba oils on protection of three wood species (Acacia nilotica, Dalbergia sissoo and Pinus wallichiana) against termite attack by Odontotermes obesus. Conditioned and pre-weighed blocks of each wood species were vacuum-pressure impregnated with a $15 \%$ concentration of the oil-ethanol solutions. Resistance of treated and untreated wood against termites was tested under laboratory as well as field conditions using choice and no-choice tests. Oil treated wood showed significant reductions in weight loss compared to control treatments. Complete termite mortality was recorded for all oil treatments except eucalyptus oil. Linseed oil showed good results in each treatment in terms of feeding resistance as well as mortality of termites followed by neem, jatropha, jojoba and eucalyptus oil. The lower weight losses were found in both choice and no-choice field tests for linseed oil treated Dalbergia sissoo while untreated Pinus wallichiana sapwood had the greater weight loss. It was observed that the oil retention was significantly more in sapwood than in heartwoods. The retention of oils justified that wood with high oil retention showed more resistance against the termite except eucalyptus oil treatment of Pinus wallichiana.
\end{abstract}

Keywords: Oil treated wood, retention, vacuum pressure, weight loss, wood protection, wood preservatives, subterranean termite.

\section{INTRODUCTION}

A number of developing countries especially Pakistan, have experienced the disastrous earthquakes in 2005 and recently in 2013. These earthquakes have oriented towards use of houses constructed with wood to limit casualties (Haseeb et al. 2011). The important timber species in Pakistan are Dalbergia sissoo Roxb. (Rosewood), Acacia nilotica L. (Prickly acacia), Eucalyptus camaldulensis Dehnh. (River red gum), Populus euphratica Oliv. (Desert poplar), Pinus wallichiana A.B. Jacks. (Blue pine), and to some extent Tectona grandis L.F. (teak) (Nouman et al. 2006, Bargali and Bargali 2009).

Termites are abundant in Pakistan with 53 species. Of these 13 are now reckoned pests of agriculture, buildings and forestry (Hassan et al. 2018). The magnitude of termite damage has not been enumerated, however, a survey indicated that $>50 \%$ of the population had little knowledge about termite damage and its economic effects, particularly in areas effected by earthquakes (Iqbal et al. 2016). Several house infesting termite species have been documented in these areas. For example, a distant report mentioned that Heterotermes indicola (Wasmann) was more abundant in Bagh and Poonch, which were epicenters of earthquake jolts (Shakoor et al. 1991). Until recently, Odonototermes obesus (Rambur) was the only species infesting wooden structures in residential areas and caused huge losses (Aihetasham and Iqbal 2012). Presently, H. indicola, Coptotermes

\footnotetext{
${ }^{1}$ Termite Research Laboratory, Department of Entomology, University of Agriculture, Faisalabad, Punjab, Pakistan. Saha786_pk@ yahoo.com

${ }^{2}$ Department of Entomology, College of Agriculture, University of Sargodha. Sargodha, Punjab, Pakistan. r_482_1980@yahoo.com •Corresponding author: sialuaf@gmail.com

Received: 01.11.2018 Accepted: 23.11.2019
} 
heimi and Microcerotermes longignathus have become the dominant species in urban ecosystems (Manzoor and Mir 2010, Hassan et al. 2017, Hassan et al. 2018, Hassan et al. 2019a).

Preservatives and wood treatment processes have extended the strength and resistance of wood against insects and fungi (Hassan et al. 2016, Hassan et al. 2019a, Hassan et al. 2019b). Waterborne, oil-borne and light organic solvent preservatives (LOSPs) are most commonly used chemical preservatives (Freeman 2008, Freeman and Mclntyre 2008). There are certain drawbacks of these chemical preservatives that includes strong odors, handling problems, painting difficulties, skin irritating for the workers, toxicity to non-target organisms and flammability (Edlich et al. 2005, Townsend and Solo-Gabriele 2010). Considering these limitations of such preservatives, another approach to protect wood is the use of hydrophobic plant/vegetable oils that are less toxic to non-target organisms and environment.

Oils of numerous plants have been tested against termites and wood decay fungi (Clausen and Yang 2008, Laredo et al. 2015). Hemp oil (Rapp and Sailer 2001), linseed and neem oil (Sailer and Rapp 2001, Paajanen and Ritschkoff 2002, Kartal et al. 2006, Temiz et al. 2013, Fatima and Morrell 2015), clove oil (Ahmed et al. 2013) and castor bean oil (Ahmed et al. 2014), all have the potential to protect wood from termite and fungal attack. Plant oils can be antimicrobial, antioxidant, antifeeding or repellent to termites as well as other invertebrates (George et al. 2014). One property of some oils, besides their toxicity, is ability to transfer a toxicant deep into the wood (Ahmed et al. 2013, Ahmed et al. 2014, Fatima and Morrell 2015). Current study evaluated five plant-derived oil (Linseed, jatropha, jojoba, neem and Eucalyptus oil) as wood preservatives. Some oil such as linseed have no or little biological activity. However, jatropha, jojoba, neem and Eucalyptus oil have been reported to have toxicity, antifeedant activity and repellency against many insects including termites (Batish et al. 2008, Singh and Sushilkumar 2008, Boateng and Kusi 2008, Manzoor et al. 2012, Himmi et al. 2013, Shafiei Alavije et al. 2014, Adebawo et al. 2015). Plant/vegetable oils have been applied using a variety of pressure and non-pressure processes (Archer and Lebow 2006) including immersion, dipping, soaking, diffusion processes and vacuum treatment (Ibach 1999). However, vacuum pressure treatment is most successful method to treat wood. The current study evaluated the wood preservative potential of five plant oils against a subterranean termite Odontotermes obesus under laboratory as well as field conditions.

\section{MATERIALS AND METHODS}

\section{Collection of termites}

A PVC pipe $(7,5 \mathrm{~cm}$ (dia.) $\times 37,5 \mathrm{~cm}$ (length) $)$ was perforated $(1,5 \mathrm{~cm}$ diameter $)$ on all sides. Corrugated cardboard $(100 \mathrm{~g})$ was rolled and put inside the pipe while capped on one end and buried in the termite infested ground, leaving $2,5 \mathrm{~cm}$ above the ground for access. (Ahmed et al. 2006). The corrugated cardboards were inspected at regular intervals for termite attack and infested cardboards were wrapped in the plastic bags and brought to the laboratory, for use in the experiments.

\section{Wood species and oils}

Defect free logs of Acacia nilotica Wild (Acacia), Dalbergia sissoo Roxb (Rosewood) and Pinus wallichiana A. B. Jacks. (Blue Pine) were purchased from the local timber market. Sapwood and heartwood were visually distinguished and were separated from each other using electric saw. Sapwood as well as heartwood samples were cut into smaller blocks ( $25 \mathrm{~mm} \times 25 \mathrm{~mm}$ x $6 \mathrm{~mm}, 13 \mathrm{~cm} \times 5 \mathrm{~cm} \times 2 \mathrm{~cm}$ or $2 \mathrm{~cm} \times 2 \mathrm{~cm} \times 3 \mathrm{~cm}$ ). Initial moisture contents of sapwood and heartwood were determined according to method adopted by Ahmed et al. (2014). Seed oils of jatropha (Jatropha curcas Linn), jojoba (Simmondsia chinensis C.K. Schneid) and linseed (Lignum usitatissimum L.), as well as, foliage oil of, Eucalyptus (Eucalyptus camaldulensis Dehnh) and Neem (Azadirachta indica A. Juss.) (purity $\geq 99$ ) were obtained from the commercial market in Faisalabad, Pakistan. The concentrations/dilutions of oil-EtOH $(15 \% \mathrm{v} / \mathrm{v})$ were prepared by using ethanol (95\% grade) as solvent (AZ Chemicals (Pvt.) Ltd.). Tested concentration (15\%) was selected for these experiments after screening series of concentrations in the previous experiments (Fatima 2015, Fatima and Morell 2015). 


\section{Treatment of woods}

Conditioned $\left(33^{\circ} \mathrm{C} ; 62 \pm 3 \% \mathrm{RH}\right)$ and pre-weighed sapwood and heartwood blocks of each wood species were impregnated with $15 \%$ concentration of the oil-EtOH solutions of each oil. Wooden blocks were placed into a glass chamber that was filled with $15 \%$ oil-EtOH solution. The chamber was evacuated for 10 min then 4 bars $(400 \mathrm{kPa})$ pressure was applied for $30 \mathrm{~min}$. The oil impregnated blocks were removed from the glass chamber, excess oil was blotted from the surface and weighed and then specimens were oven dried at $100^{\circ} \mathrm{C}$ for 12 hours. Untreated or solvent treated $\left(95 \%\right.$ ethanol) wood blocks dried at $100^{\circ} \mathrm{C}$ for 12 hours were considered as a control treatment.

Retention of heartwood and sapwood blocks $(2 \times 2 \times 3 \mathrm{~cm})$ was measured using method adopted by Liibert et al. (2012). Impregnation procedure was identical for all wood species and oil solutions as described above. Retention $\left(\mathrm{kg} / \mathrm{m}^{3}\right)$ was calculated using following Equation 1.

$$
\text { Retencion }=\frac{G x C}{V}
$$

where G: (T2-T1) is absorbed solution in sample in kilograms, $\mathrm{C}$ is concentration of solution, and V is volume of sample in cubic meters.

\section{Laboratory termite bioassays}

\section{Wood weight loss (choice and no-choice tests)}

For the no-choice tests, treated and untreated sapwood and heartwood blocks exposed to the termites were arranged in Completely Randomized Design (CRD) using three replications. Each replication consist of three sapwood or heartwood blocks. The blocks $(25 \times 25 \times 6 \mathrm{~mm})$ were subjected to termite attack in previously described apparatus (Fatima et al. 2015) (Figure 1).
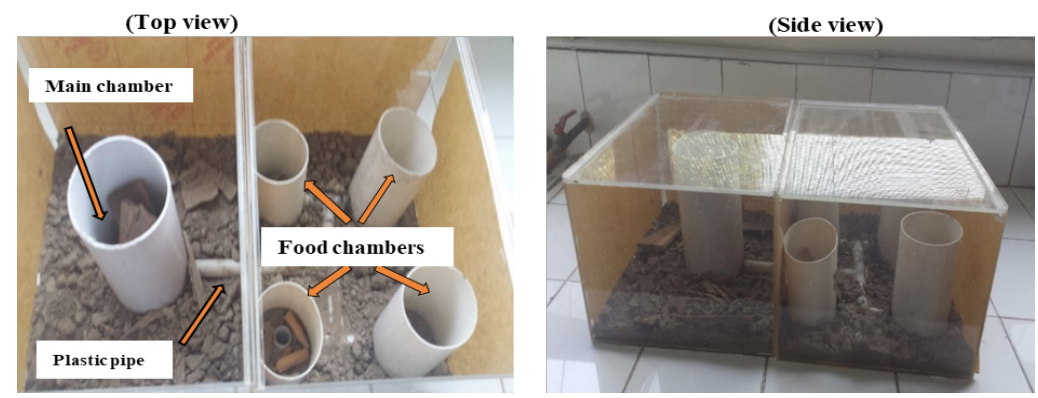

Figure 1: Apparatus designed for the laboratory experiments.

Three sapwood or heartwood blocks of one wood species were treated with a given oil were tied together and placed in one chamber as the single choice food for termites while untreated and solvent treated control sapwood or heartwood blocks ( 3 blocks tied together) were placed in a separate chamber. Sapwood and heartwood blocks of each species were tested separately. A total of 1000 active termite workers and 50 soldiers were released into a central plastic chamber. Experimental units were incubated at $\left(27 \pm 2{ }^{\circ} \mathrm{C}\right.$ and $\left.85 \pm 5 \% \mathrm{RH}\right)$ for 4 weeks. The infested blocks were removed from the chambers and dried at $100^{\circ} \mathrm{C}$ for 24 hours, cleaned with a brush and weighed. Weight loss percentage was calculated using following Equation 2 (Ahmed at al. 2014).

$$
\text { Weight loss }=\frac{W_{1}-W_{2}}{W_{1}}
$$


Where $\mathrm{W}_{1}$ is the weight of the block before termite exposure and $\mathrm{W}_{2}$ is the weight of the block after termite exposure.

For the choice tests, three blocks (sapwood or heartwood) one from each tested wood species treated with each oil were tied together and considered as one replicate. Sapwood and heartwood treated with each oil were tested separately. Untreated/solvent treated sapwood or heartwood blocks were used as control treatment and all treatments were replicated three times. Treated blocks were exposed to termites in chamber for four weeks. At the end of the test period, percent weight loss was determined as described above.

\section{Mortality of termites (choice and no-choice tests)}

Blocks $(2 \mathrm{~cm} \times 2 \mathrm{~cm} \times 3 \mathrm{~cm})$ of different wood species for both choice and no-choice tests were placed in a glass jar $(1 \mathrm{~L})$ filled with sterilized sand $(500 \mathrm{~g})$. Treated conditioned and weighed blocks along with untreated/ solvent treated controls were placed on the surface of sand. A total of 200 termite workers and 20 soldiers were released in each jar which were incubated at $27 \pm 2{ }^{\circ} \mathrm{C}$ and $85 \pm 5 \% \mathrm{RH}$ for 4 weeks. Live termite were counted at the end of the test period to calculate percent mortality of termites.

\section{Field Bioassays (choice and no-choice tests)}

The treatment, arrangement and binding of wooded blocks $(13 \times 5 \times 2 \mathrm{~cm})$ for choice and no-choice tests were similar to those described for the laboratory tests. The exposure of treated and untreated specimens to the termites was arranged in Randomized Complete Block Design (RCBD) using three replications. The treated blocks were subjected to termite attack in underground concrete chamber (Ahmed et al. 2014, Fatima et al. 2015 ) for a period of 4 weeks. At the end of the experiment, infested blocks were cleaned, oven dried and weighed to determine weight loss.

\section{Statistical analysis}

Weight loss and mortality data in the no-choice test were analyzed using 2-way nested ANOVA with wood type and oil type as factors, assuming blocks as independent variable. However, weight loss data from the choice test were analyzed using a split-plot design with block pairs within each wood type. Termite mortality in the choice test was analyzed using Exact Wilcoxon test. Means of treatments were separated using Tukey HSD test at the $5 \%$ level of significance.

\section{RESULTS}

\section{Wood weight loss under laboratory conditions}

ANOVA revealed the significant interactions among oil type $(p<0,001)$ and non-significant interaction $(\mathrm{p}>0,05)$ for the wood type (sapwood and heartwood) in the choice and no-choice tests for A. nilotica wood. Minimum weight losses of sapwood and heartwood were observed after treatment with linseed oil followed by jatropha and jojoba oil at the tested concentration in both tests. Untreated or solvent treated control blocks of sapwood and heartwood of $A$. nilotica exhibited highest weight losses ( $>27 \%)$. However, weight loss of $A$. nilotica heartwood after treatment with neem oil differ non-significantly with weight loss of linseed oil treated sapwood and heartwood in choice test. Eucalyptus oil treated sapwood and heartwood showed significantly higher weight losses compared to linseed oil treated wood of this species (Figure 2a).

Minimum weight losses of $D$. sissoo were recorded for jatropha and linseed oil treated sapwood followed by heartwood treated with these oils. Resistance of treated wood to termite varies significantly after treatment of different oil $(p<0,001)$, similarly resistance of sapwood and heartwood after treatment with each oil varies significantly $(\mathrm{p}<0,001)$. Significantly higher weight losses $(>5 \%)$ were observed in neem and Eucalyptus oil treated sapwood and heartwood of D. sissoo compared to other tested oils in both tests (Figure 2b).

Similarly, linseed and jatropha oils were also very effective in protecting $P$. wallichiana sapwood and heartwood against $O$. obesus in choice and no-choice tests. Weight losses of $P$. wallichiana sapwood and heartwood were significantly reduced after treatment with these two oil than other oil treatments. Control blocks of $P$. wallichiana sapwood and heartwood were significantly more consumed by $O$. obesus compared to all other 
treatments. No-significant difference in weight losses of $P$. wallichiana sapwood and heartwood was observed after each oil treatment $(\mathrm{p}<0,001)$ (Figure $2 \mathrm{c})$.

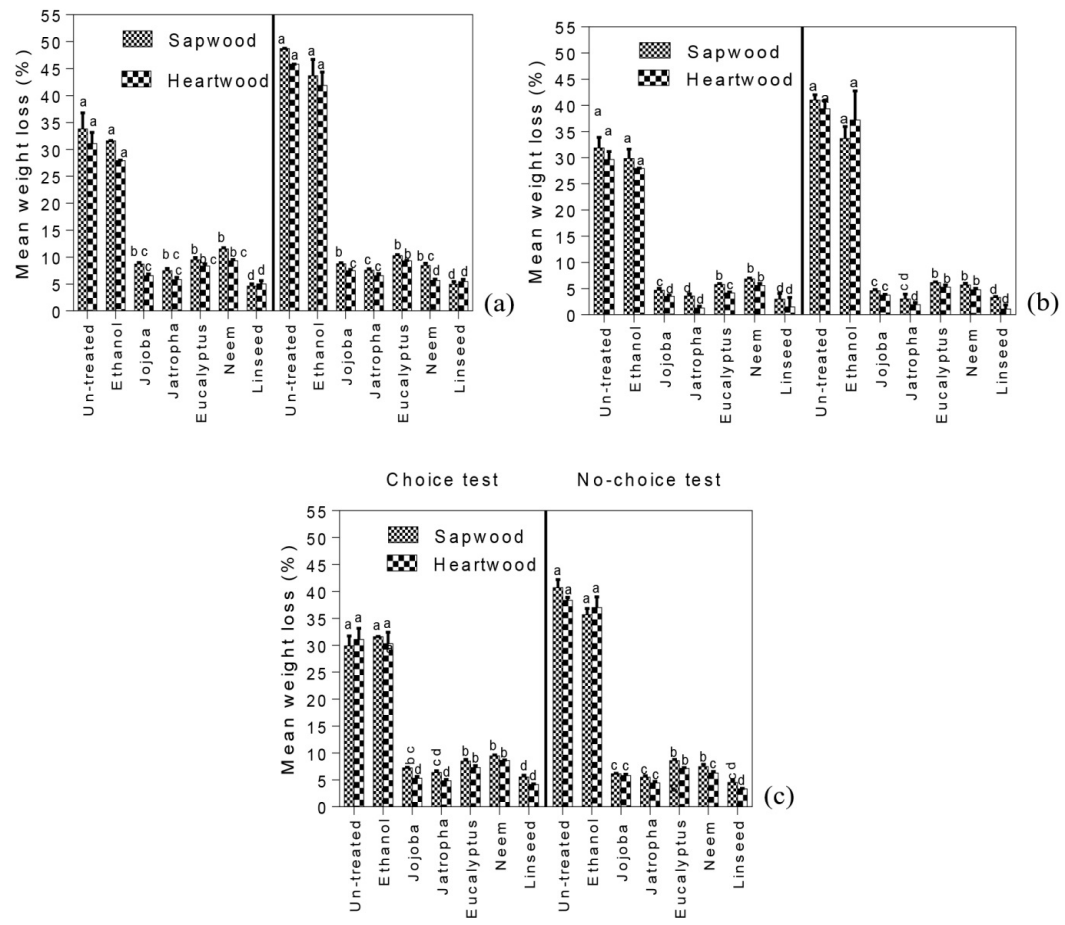

Figure 2: Mean weight losses of (a) A. nilotica (b) D. sissoo and (c) P. wallichiana sapwood and heartwood treated with different oils after exposure to $O$. obesus in choice and no-choice laboratory tests.

\section{Termite mortality}

Termites fed on untreated/solvent treated A. nilotica, D. sissoo and $P$. wallichiana sapwood and heartwood showed significantly minimum mortality $(<15 \%)$ in choice and no-choice tests. Maximum mortality was observed when termites were fed on linseed, neem and jojoba oil treated sapwood and heartwood of $A$. nilotica, D. sissoo and P. wallichiana in both tests and mortality was $>90 \%$. However, significantly lower mortality of termite when fed on A. nilotica and D. sissoo sapwood and heartwood treated with jatropha and Eucalyptus oil was observed compared to other oil treatments in both tests (Figure 3a, Figure 3b and Figure 3c). Linseed, neem, jatropha and jojoba oil oils were equally retained by $A$. nilotica sapwood and heartwood and there was significantly lower retention of Eucalyptus oil in both woods. Dalbergia sissoo heartwood and sapwood showed significantly lower retention of eucalyptus and linseed oil compared to other oil treatments (Figure 4a, and Figure $4 \mathrm{~b}$ ). Pinus wallichiana sapwood and heartwood showed significantly less resistance against termite when treated with Eucalyptus oil compared to other oil treatments in both tests (Figure 3c). Neem and eucalyptus oils were retained in significantly lower amounts compared to other oil treatments in this wood species (Figure 4a, Figure 4b). 

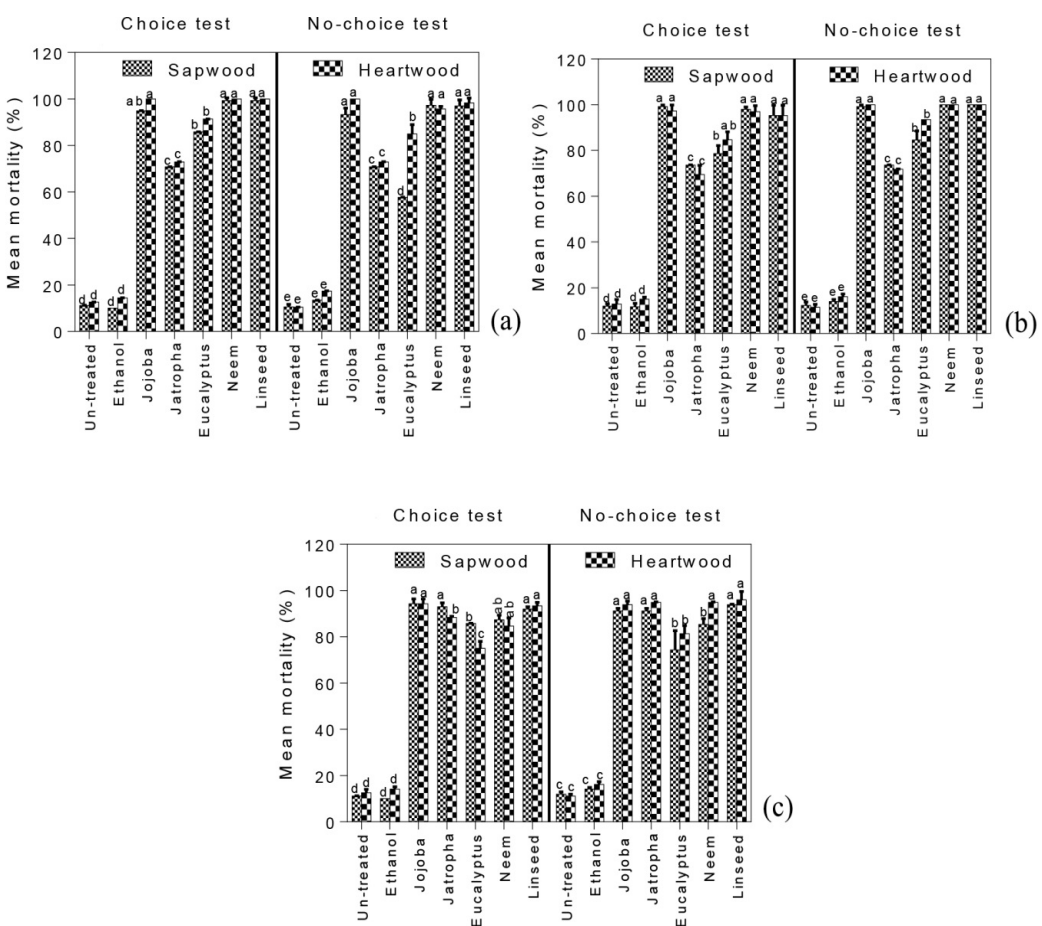

Figure 3: Mean mortality of $O$. obesus after feeding on (a) A. nilotica (b) D. sissoo and (c) P. wallichiana sapwood and heartwood treated with different oils in choice and no-choice laboratory tests.
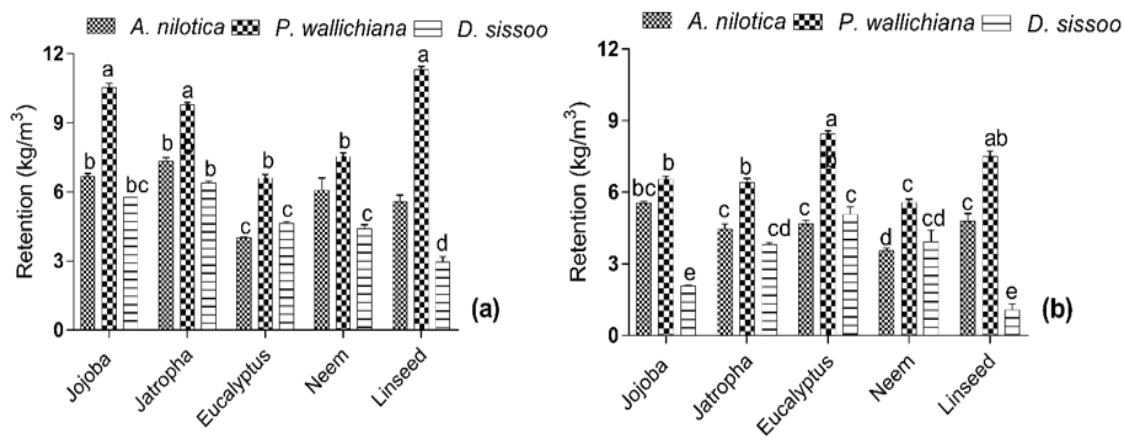

Figure 4: Retention of treatment solutions in (a) sapwood and (b) heartwood of A. nilotica, D. sissoo and P. wallichiana.

\section{Wood weight loss under field conditions}

Oil treated sapwood and heartwood of three species showed significantly minimum weight loss than untreated wood in both tests. Linseed oil treated D. sissoo heartwood showed minimum weight loss $(<3 \%)$ followed by $P$. wallichiana and A. nilotica linseed oil treated heartwoods. Weight losses of sapwood of all three species differ non-significantly after treatment with jatropha, jojoba and Eucalyptus oil in both tests (Figure 5a, Figure 5b and Figure 5c). 

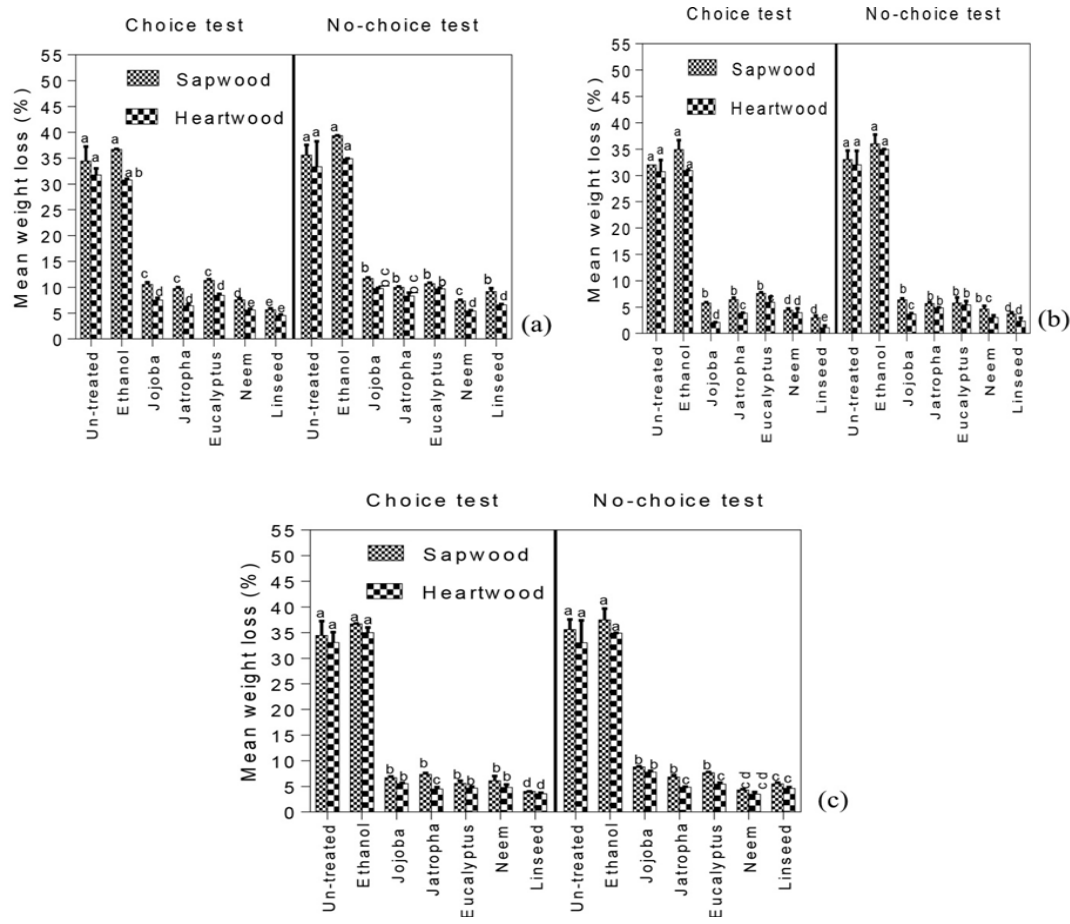

Figure 5: Mean weight losses of (a) A. nilotica (b) D. sissoo and (c) P. wallichiana sapwood and heartwood treated with different oils after exposure to $O$. obesus in choice and no-choice field tests.

\section{DISCUSSION}

The results of present studies demonstrate the preservative potential of various oils to protect three wood species under laboratory and field conditions. The treatments significantly reduced the weight loss and increased termite mortality in both choice and no-choice tests. Linseed, neem, and jojoba oil produced better termite resistance than jatropha and Eucalyptus oil treatments in the laboratory conditions. However, overall all treatments were equally effective in field conditions. Nevertheless, linseed oil showed relatively more protective effect against termite on all wood species. Previous studies also showed similar improvement in termite resistance after vacuum pressure oil application of oils (Koski 2008, Unsal et al. 2009, Manalo and Acda 2009). Kukui oil improved resistance to Coptotermes formosanus (Nakayama and Osbrink 2010). Neem oil in combination with copper and cashew nut shell liquid produced protection against the termite on rubber wood (Venmalar and Nagaveni 2005). Neem oil also improved resistance of Triplochiton scleroxylon (Obeche) against termite attack (Thlama et al. 2012). Ahmed et al. (2014) reported similar results on A. nilotica sap-and heartwoods treated with castor bean oil ( $R$. communis) exposed to O. obesus. Linseed followed by neem oil treated wood showed the highest resistance to termite attack. This result confirmed previous reports where linseed oil treated Japanese cedar (Cryptomeria japonica D. Don) and beech (Fagus crenata Blume) woods showed reduced weight losses against $C$. formosanus attack (Lyon et al. 2007, Moyin-Jesu 2010). Scots pine sapwood impregnated with linseed oil increased resistance against bio-deterioration (Siau 1972, Van Eckeveld et al. 2001). Linseed oil heat treated Radiata pine improved resistance against decay fungi and termites (Dubey 2010). Insecticidal and antifeedant properties of Jatropha oil have been reported against a number of insects (Singh and Sushilkumar 2008). Jatropha oil reduced feeding and increased mortality rate in C. vastator (Acda and Michaud 2009). In the current study, this oil was also effective in protecting wood but killed lower number of termites compared to other oil treatments except Eucalyptus oil in choice and no-choice tests. Eucalyptus oil proved to be toxic and repellent to termites (Manzoor et al. 2012) but it provided less resistance to three 
wood species and killed lower number of termites in both tests compared to other oil treatments. Previous studied shows that this oil is toxicant with contact and digestive toxicity against termites (Nerio et al. 2010, Alavijeh et al. 2014). Linseed oil is considered to have no toxic action against wood deteriorating organism but it provided more resistance to all three wood species against termites. One possible mechanism of this oil could be creating hydrophobic barrier that resulted in displacement of water in woods with oil and prevented O. obesus feeding. (Lyon et al. 2007). The retention of oils justified that wood with high oil retention resisted termites. Oil retention was higher in sapwood of each wood species as compared to corresponding heartwood. Pine sapwood and heartwood had higher oil uptake in comparison with other species (Sidorova 2009). There is no comparative evidence of the research conducted on vacuum pressure cold oil application and its effect on oil retention with reference to different wood species. Globally, different researchers to determine retention or weight gain after oil heat treatment of wood have carried out most of the work.

\section{CONCLUSIONS}

These results illustrates the benefits of pressure impregnation of wood with plant-derived oils. Treatment with linseed, neem, jatropha and jojoba oil significantly reduced wood weight loss of A. nilotica, D. sissoo and $P$. wallichiana and increased the termite mortality.

\section{ACKNOWLEDGEMENTS}

This research is part of Rushda Fatima PhD project and authors wish to thank Higher Education Commission of Pakistan (HEC) for provision of funds for the completion of this project.

\section{REFERENCES}

Acda, M.N.; Michaud, J. 2009. Toxicity, tunneling and feeding behavior of the termite, Coptotermes vastator in sand treated with oil of the physic nut, Jatropha curcas. Journal of Insect Science 9(1): 1-8. https:// doi.org/10.1673/031.009.6401.

Adebawo, F.G.; Ajala, O.O.; Olatunji, O.A.; Adekanbi, T.J. 2015. Potentials of Azadirachta indica seed oil as biopreservative against termite attack on wood. Asian Journal of Plant Science and Research 5(12): $1-5$.

Ahmed, S.; Fatima, R.; Nisar, M.; Hassan, B. 2014. Evaluation of castor bean oil on Acacia nilotica as wood preservative against Odontotermes obesus (Ramb.)(Termitidae: Isoptera). International Wood Products Journal 5(1): 5-10. https://doi.org/10.1179/2042645313 Y.0000000053.

Ahmed, S.; Nisar, M.S.; Naseer, B.; Hassan, B.; Shakir, M.M.2013. Determination of wood protection by seasoning and clove oil application against Odontotermes obesus Ramb (Termitidae: Isoptera). Pakistan Entomologist 35(2): 83-87.

Ahmed, S.; Riaz M.A.; Shahid. M. 2006. Response of Microtermes obesi (Isoptera: Termitidae) and its gut bacteria towards some plant extracts. Journal of Food Agriculture and Environment 4(1): 317-320.

Aihetasham, A.; Iqbal, S. 2012. Feeding preferences of Microcerotermes championi (Snyder) for different wooden blocks dried at different temperatures under forced and choice feeding conditions in laboratory and field. Pakistan Journal of Zoology 44(4): 1137-1144. 
Alavijeh, E.S.; Habibpour, B.; Moharramipour, S.; Rasekh, A. 2014. Bioactivity of Eucalyptus camaldulensis essential oil against Microcerotermes diversus (Isoptera: Termitidae). Journal of Crop Protection 3(1): $1-11$.

Archer, K.; Lebow, S. 2006. Wood preservation. In: J. C. F. Walker (ed.). Primary wood processing: Principles and Practice. Dordrecht: Springer 297-338. https://www.springer.com/gp/book/9789401581103. 11-19.

Bargali, K.; Bargali, S. 2009. Acacia nilotica a multipurpose leguminous plant. Nature and Science 7(4):

Batish, D.R.; Singh, H.P.; Kohli, R.K.; Kaur, S. 2008. Eucalyptus essential oil as a natural pesticide. Forest Ecology and Management 256(12): 2166-2174. https://doi.org/10.1016/j.foreco.2008.08.008.

Boateng, B.; Kusi, F. 2008. Toxicity of Jatropha seed oil to Callosobruchus maculatus (Coleoptera: Bruchidae) and its parasitoid, Dinarmus basalis (Hymenoptera: Pteromalidae). Journal of Applied Sciences Research 4(8): 945-951.

Clausen, C.A.; Yang, V.W. 2008. Fumigant toxicity of essential oils to Reticulitermes flavipes. Proceedings, 104th annual meeting of the American Wood Protection Association. Portland, Oregon, May 18-20 2008: volume 104. Birmingham, Ala.: American Wood Protection Association c2008: 49-54.

Dubey, M.K. 2010. Improvements in stability, durability and mechanical properties of Radiata pine wood after heat-treatment in a vegetable oil. Doctoral Thesis University of Canterbury. http://hdl.handle. net/10092/3856.

Edlich, R.; Winters K.L.; Long Iii, W.B. 2005. Treated wood preservatives linked to aquatic damage, human illness, and death-a societal problem. Journal of Long-Term Effects of Medical Implants 15(2): 209224. https://doi.org/10.1615/jlongtermeffmedimplants.v15.i2.80.

Fatima, R.; Ahmed, S.; Arshad, M.; Sahi, S.T. 2015. Effect of seasoning of different woods on resistance against Odontotermes obesus (Ramb.) under laboratory and field choice and no-choice tests. BioResources 10(4): 6363-6377. http://dx.doi.org/10.15376/biores.10.4.6363-6377.

Fatima, R.; Morrell, J.J. 2015. Ability of plant-derived oils to inhibit damp wood termite Zootermopsis augusticollis activity. Maderas Ciencia y Tecnología 17(3): 685-690. http://dx.doi.org/10.4067/S0718221X2015005000060.

Fatima, R. 2015. Determination of natural resistance of wood and efficacy of oil for wood protection against termites in Punjab, Pakistan. Doctoral thesis, University of Agriculture Faisalabad Pakistan. http://prr. hec.gov.pk/jspui/handle/123456789/7834.

Freeman, M.H.; Mclntyre, C.R. 2008. A comprehensive review of copper-based wood preservatives. Forest Products Journal 58(11): 6-27.

Freeman, M.H. 2008. Wood preservative formulation development and systems: Organic and inorganic based systems. Development of Commercial Wood Preservatives: Efficacy, Environmental, and Health Issues. ACS Symposium Series. ACS Publications 408-426. https://doi.org/10.1021/bk-2008-0982.ch024.

George, D.R.; Finn, R.D.; Graham, K.M; Sparagano, O.A. 2014. Present and future potential of plant-derived products to control arthropods of veterinary and medical significance. Parasites \& Vectors 7(1): 28. http://dx.doi.org/10.1186/1756-3305-7-28.

Haseeb, M.; Xinhailu, A.B.; Khan, J.Z.; Ahmad, I.; Malik, R. 2011. Construction of earthquake resistant buildings and infrastructure implementing seismic design and building code in northern Pakistan 2005 earthquake affected area. International Journal of Business and Social Science 2(4): 168-177.

Hassan, B.; Ahmed, S.; Kirker, G.; Mankowski, M.E.; Misbah-Ul-Haq, M. 2018. Antioxidant effects of four heartwood extractives on midgut enzyme activity in Heterotermes indicola (Blattodea: Rhinotermitidae). Environmental entomology 47(3): 741-748. https://doi.org/10.1093/ee/nvy029. 
Hassan, B.; Ahmed, S.; Mehmood, N.; Mankowski, M.E.; Misbah-Ul-Haq, M. 2019a. Toxicity potential of heartwood extractives from two mulberry species against Heterotermes indicola. Maderas. Ciencia $y$ Tecnología 21(2): 153-162. http://dx.doi.org/10.4067/S0718-221X2019005000203.

Hassan, B.; Mankowski, M.; Kirker, G.T.; Ahmed, S.; UI Haq, M.M. 2016. Antitermitic activities of Shisham Dalbergia sissoo (Roxb.) heartwood extractives against two termite species. Proceedings IRG Annual Meeting (ISSN 2000-8953), IRG/WP 16-10856, The International Research Group On Wood Protection. $1-16$.

Hassan, B.; Mankowski, M.E.; Kirker, G.; Ahmed, S. 2017. Effects of heartwood extractives on symbiotic protozoan communities and mortality in two termite species. International Biodeterioration \& Biodegradation 123: 27-36. https://doi.org/10.1016/j.ibiod.2017.05.023.

Hassan, B.; Mankowski, M.E.; Kirker, G.; Ahmed, S.; Bishell, A. 2019b. Ex-situ performance of extracts from naturally durable heartwood species and their potential as wood preservatives. European Journal of Wood and Wood Products 77(5): 869-878. https://doi.org/10.1007/s00107-019-01443-6.

Himmi, S.K.; Tarmadi, D.; Ismayati, M.; Yusuf, S. 2013. Bioefficacy performance of neem-based formulation on wood protection and soil barrier against subterranean termite, Coptotermes gestroi Wasmann (Isoptera: Rhinotermitidae). Procedia Environmental Sciences 17: 135-141. https://doi.org/10.1016/j. proenv.2013.02.021.

Ibach, R.E. 1999. Wood handbook-Wood as an engineering material. Gen. Tech. Replications. FPLGTR-113. Madison, WI: U.S. Department of Agriculture, Forest Service, Forest Products Laboratory. 463p. https://www.fpl.fs.fed.us/documnts/fplgtr/fpl_gtr190.pdfhttps://www.fpl.fs.fed.us/documnts/fplgtr/fpl_ gtr190.pdf.

Iqbal, N.; Khan, H.A.A.; Alvi, A. M.; Saeed, S.; Khan, T.; Ali, S.; Saeed, Q. 2016. Knowledge, attitude and practices of household people about termites in southern Punjab, Pakistan. Journal of Entomology and Zoolgy Studies 4 (5): 17-21.

Kartal, S.N.; Hwang, W.J.; Imamura, Y.; Sekine, Y. 2006. Effect of essential oil compounds and plant extracts on decay and termite resistance of wood. Holz als Roh-und Werkstoff 64(6):455-461. https://doi. org/10.1007/s00107-006-0098-8.

Koski, A. 2008. Applicability of crude tar oil for wood protection. Ph.D. Thesis. Faculty of Technology Dept. Process and Environ Engin. Univ. Oulu, Finland. http://jultika.oulu.fi/files/isbn9789514287237.pdf.

Laredo, R.F.G.; Castro, M.R.; Guzmán, N.E.R.; Infante, J.A.G.; Moreno-Jiménez, M.R.; Karchesy, J.J. 2015. Wood preservation using natural products. Madera y Bosques 21: 63-76. https://doi.org/10.21829/ myb.2015.210427.

Liibert, L.; Treu, A.; Kers, J.; Meier, P. 2012. Potential eco-friendly wood protection systems used in royal process. Proceeding of 8th International DAAAM Baltic Conference-Industrial Engineering. 19-21. Tallinn, Estonia.

Lyon, F.; Thevenon, M.F.; Hwang, W.J.; Imamura, Y.; Gril, J.; Pizzi, A. 2007. Effect of an oil heat treatment on the leachability and biological resistance of boric acid impregnated wood. Annals of Forest Science 64(6): 673-678. https://doi.org/10.1051/forest:2007046.

Manalo, R.; Acda, M. 2009. Effects of hot oil treatment on physical and mechanical properties of three species of Philippine bamboo. Journal of Tropical Forest Science 21 (1): 19-24.

Manzoor, F.; Malik, S.A.; Naz, N.; Naz, S. 2012. Potential of antitermitic activities of eucalyptus oil. Pakistan Journal of Zoology 44(2): 335-339.

Manzoor, F.; Mir, N. 2010. Survey of termite infested houses, indigenous building materials and construction techniques in Pakistan. Pakistan Journal of Zoology 42(6): 693-696. 
Moyin-Jesu, E. 2010. Comparative evaluation of modified neem leaf, wood ash and neem leaf extracts for seed treatment and pest control in maize (Zea mays 1.). Emirates Journal of Food and Agriculture 3 (1): 90-97. https://doi.org/10.4236/as.2012.31012.

Nakayama, F.; Osbrink, W. 2010. Evaluation of kukui oil (Aleurites moluccana) for controlling termites. Industrial Crops and Products 31(2): 312-315. https://doi.org/10.1016/j.indcrop.2009.11.009.

Nerio, L.S.; Olivero-Verbel, J.; Stashenko, E. 2010. Repellent activity of essential oils: a review. BioResource Technology 101 (1): 372-378. https://doi.org/10.1016/j.biortech.2009.07.048.

Nouman, W.; Khan, G.; Farooq, H.; Jamal, N. 2006. An investigation to find out the reasons for adoption of agroforestry by farmers in district Faisalabad. J Anim Plant Sci 16(3-4): 93-95.

Paajanen, L.; Ritschkofft, A. 2002. Effect of crude tall oil, linseed oil and rapeseed oil on the growth of the decay fungi, the international research group on wood preservation. In Proceedings IRG Annual Meeting IRG/WP. 02-30299.The International Research Group on Wood Protection: Cardiff, Wales, UK.

Rapp, A.O.; Sailer, M. 2001. Oil heat treatment of wood in Germany state of the art. European commission, directorate-general for research EUR 19885, COST Action E22 Special Seminar $9^{\text {th }}$ February 2001, Antibes, France, pp. 47-64.

Sailer, M.A.; Rapp, O. 2001. Use of vegetable oils for wood protection. COST Action E22: Environmental optimization of wood protection. Conference in Einbeck Germany.

Shafiei Alavije, E.; Habibpour, B.; Moharramipour, S.; Rasekh, A. 2014. Bioactivity of Eucalyptus camaldulensis essential oil against Microcerotermes diversus (Isoptera: Termitidae). Journal of Crop Protection 3(1): 1-11.

Shakoor, A.; Akhtar, M.; Awan, S. 1991. Feeding preferences of termites of Azad Kashmir (Pakistan). Pakistan Journal of Zoology 23: 355-359.

Siau, J. 1972. The effects of specimen length and impregnation time upon the retention of oils in wood. Wood Science 4(3): 163-170.

Sidorova, K. 2009. Oil heat treatment of wood. In Proceedings of the 4 meeting of the Nordic Baltic network in wood. https://www.ltu.se/cms fs/1.44305!/oil\%20heat\%20treatment\%20of\%20wood.pdf.

Singh, N.; Sushilkumar, A. 2008. Anti-termite activity of Jatropha curcas (linn). Biochemicals. Journal of Applied Sciences and Environmental Management 12 (3): 67-69. http://dx.doi.org/10.4314/jasem. v12i3.55498.

Temiz, A.; Kose, G.; Panov, D.; Terziev, N.; Alma, M.H.; Palanti, S.; Akbas, S. 2013. Effect of bio-oil and epoxidized linseed oil on physical, mechanical, and biological properties of treated wood. Journal of Applied Polymer Science 130(3): 1562-1569. https://doi.org/10.1002/app.39334.

Thlama, D.; Falemara, B.; Ameh, M.; Osasebor, O. 2012. Mitigating climate change effects using eco-friendly wood preservatives. Journal of Nature and Science 2 (2): 29-40. https://doi.org/10.1016/j. ibiod.2009.02.001.

Townsend T.G.; Solo-Gabriele, H. 2010. Environmental impacts of treated wood. CRC Press. https://www. crcpress.com/Environmental-Impacts-of-Treated-Wood/Townsend-Solo-Gabriele/p/book/9780849364952.

Unsal, O.; Kartal, S.N.; Candan, Z.; Arango, R.A.; Clausen, C.A.; Green, F. 2009. Decay and termite resistance, water absorption and swelling of thermally compressed wood panels. International Biodeterioration \& Biodegradation 63: 548-552. https://doi.org/10.1016/j.ibiod.2009.02.001.

Van Eckeveld, A.; Homan, W.J.; Militz, H. 2001. Increasing the water repellency of Scots pine sapwood by impregnation with undiluted linseed oil, wood oil, coccos oil and tall oil. Holzforsch. Holzverwert 53: 113115. 
Venmalar, D.; Nagveni, H. C. 2005. Evaluation of copperised cashew nut shell liquid and neem oil as wood preservatives. In Proceedings 36th IRG Annual Meeting IRG/ WP 05-30368. The International Research Group on Wood Protection: Bangalore, India. 